\title{
ECOLOGICAL NICHE OF FAMILY FARMERS IN SOUTHERN MINAS GERAIS STATE (BRAZIL)
}

\author{
CAVALLINI, M. M. and NORDI, N. \\ Laboratório de Ecologia Humana e Etnoecologia, Departamento de Hidrobiologia, Universidade Federal de São \\ Carlos, UFSCar, Via Washington Luís, km 235, CEP 13565-905, São Carlos, SP, Brazil \\ Correspondence to: Nivaldo Nordi, Laboratório de Ecologia Humana e Etnoecologia, Departamento de \\ Hidrobiologia, Universidade Federal de São Carlos, UFSCar, Via Washington Luís, km 235, \\ CEP 13565-905, São Carlos, SP, Brazil, e-mail: nivaldo@power.ufscar.br
}

Received June 18, 2003 - Accepted September 10, 2003 - Distributed February 28, 2005

(With 3 figures)

\begin{abstract}
The concept of ecological niche, considered by the food dimension point of view, was used to characterize a small farmers community from the south of Minas Gerais State (Brazil). Ten small farmer families and 76 different meals eaten by them were evaluated in this study, during three different periods: September 1995 (end of the dry season), December 1995 (rainy season) and April 1996 (end of the rainy season). The analysed community appeared to depend markedly on certain food items showing little seasonal variation in their diet and appeared also to be self-sufficient in food supply, with satisfactory nutritional status. The food niche breadth for the studied small farmer families was always below $50 \%$, with high seasonal overlap of the food niche, around $72 \%$ to $80 \%$. The results are discussed based on social-cultural, economical and agrarian context.
\end{abstract}

Key words: food energy, ecological niche, food dimension niche, small farmer families.

\section{RESUMO}

\section{Nicho ecológico de agricultores familiares da região sul do Estado de Minas Gerais (Brasil)}

O conceito de nicho ecológico, considerado do ponto de vista da dimensão alimento, foi usado para caracterizar uma comunidade de pequenos agricultores do sul do Estado de Minas Gerais (Brasil). Dez famílias de pequenos agricultores e 76 diferentes refeições consumidas por elas foram avaliadas neste estudo, durante três períodos diferentes: setembro de 95 (fim da estação seca), dezembro de 95 (estação chuvosa) e abril de 96 (fim da estação chuvosa). A comunidade analisada pareceu depender marcadamente de determinados itens alimentares, mostrando pouca variação sazonal em sua dieta, e também ser autosuficiente quanto ao suprimento alimentar, com satisfatório estado nutricional. A largura do nicho alimentar para as famílias de pequenos agricultores estudadas esteve sempre abaixo de $50 \%$, com alta sobreposição sazonal, variando de $72 \%$ a $80 \%$. Os resultados são discutidos com base nos contextos sócio-cultural, econômico e agrário.

Palavras-chave: energia alimentar, nicho ecológico, dimensão alimentar do nicho, famílias de pequenos agricultores.

\section{INTRODUCTION}

The ecological niche can be defined as: the environmental conditions and resources necessary to a normal development of a population (Begon, 1988). This ecological niche concept was developed by Hutchinson (1957), and it was entitled as multidimensional or Hutchinsonian niche. The multidimensional niche concept is one of the most adequate tools to study interactions between man and its surrounding environment. The utility of ecological niche concept, applied to the man, was firstly discussed 
and systematized by Hardesty (1972) and has been useful to understand the use of natural resources by human populations (Begossi, 1994).

The use of ecological niche concept has allowed evaluating the food resources dependence degree and seasonal variations on a diet of a person, families or communities of local social groups. This approach also allows establishing important relations among the analysis units, which diet may differ depending on social, economical and cultural factors, or on the distinctive ways of using resources (Hardesty, 1975).

The studied rural community belongs to Pouso Alto municipality, located on South region of Minas Gerais State. The farming and cattle activities are sustained by familiar work. During the summer cultivation season ("época de planta" = plant time), the studied farmers use the exchange work days as a strategy to increase the independence of external laborer. Besides this, according to Queiroz (1976), these work cooperation have the important function of aggregation and social cohesion. The farmer properties are small, owned or rented, and they are used to several purposes as to plant cultivation, cattle pasture (natural or cultivated) and maintenance of nature vegetation.

Based on Toledo (1990), the studied farmers belongs to the peasant class and can be characterized as: (a) "a main feature of peasant production is its relatively high self-sufficiency, and peasant families consume a substantial portion of their own production"; (b) peasants are engaged in a production process predominantly based on family labour"; (c) "human and animal power, rather than fossil fuels, are the main sources of energy"; (d) "the combined production of use values (goods consumed by families) and exchange values (goods circulated as commodities)"; (e) "peasants, generally, are smallscale landowners"; (f) "although agriculture tends to be the main activity of peasant households, peasant subsistence is based on a combination of practices". These characteristics are also frequently found in a great number of other Brazilian family farmers.

The present work was done to characterize the food universe of a rural community composed of small farmers (familiar agriculture), using the ecological niche concept by the point of view of food dimension. The breadth (specilization) and the seasonal variation (flexibility) of small farmers families food niche were determined to know the variety of consumed food and their dependence of specific food. We supposed that the small farmers families studied present selfsufficiency ingest, because they are relatively independent of external factors (merchandising) and they have strategies (diversified production and capacity of to stock food) to prevent environmental cycles variation. The fitting of family caloric ingest to the energy wasted on agricultural activities, was also investigated based on Cavallini (2001).

\section{METHODOLOGY}

The 24-hr recall method was used for ingest characterization of ten studied families, where the interviewers describe the various food items present in their last meal (lunch or dinner). The size of studied families was composed of four or five components. An overall number of 76 meals were sampled during the period of September 1995 (end of the dry season), December 1995 (rainy season) and April 1996 (end of the rainy season). The data obtained from meal sampling allowed determining the families' niche breadth and the overlap in the food dimension. The index used to obtain the niche breadth were the Levins' index (Krebs, 1989). The Levins' index can be expressed as:

Where:

$$
B=1 / \Sigma\left(p_{j}^{2}\right)
$$

$\mathrm{B}=$ Levins' measure of niche breadth;

$\mathrm{p}_{\mathrm{j}}=$ fraction of items in the diet that are of food category $\mathrm{j}$.

This index reaches a maximum value when the individuals consume all the items observed in the sampled meals in a similar proportion (generalists). When this index approaches to a minimum value means that all of the individuals use one or a just a few of the sampled food resources (specialists). According to Levins's index, B may change from 1 to $\mathrm{n}$, where $n$ represents the richness or the overall number of food items observed in the sampled meals.

The overlap percentage of food niche breadth indexes was determined at different times of the year and for different family units. This item was done employing the method described by Krebs (1989), which is considered one of the simplest and most attractive measures of niche overlap. This measure is calculated as a percentage and is given by:

$$
\mathrm{P}_{\mathrm{jk}}=\left[\Sigma^{\mathrm{n}}\left(\text { minimum } p_{\mathrm{jk}}, p_{i k}\right)\right] .100
$$


Where:

$P_{j k}=$ percentage of seasonal niche overlap between periods $\mathrm{j}$ and $\mathrm{k}$;

$\mathrm{p}_{\mathrm{ij}}, \mathrm{p}_{\mathrm{ik}}=$ proportion of food items $\mathrm{i}$ in the meals of the studied families during periods $j$ and $\mathrm{k}$;

$n=$ total number of resource states (number of food items - richness).

\section{RESULTS AND DISCUSSION}

The main food items incorporated in the diet of the studied rural farmers (Table 1) are: rice, beans, potato, chicken and pasta. These items were generally found in high frequency and during all of the studied sample period. Other items as lettuce, tomato, carrot, pumpkin, beef and pork, were also commonly observed in the food ingest of the studied small farmers, although less frequently. The remaining items, showed in Table 1, were available only at specific times of the year and they generally have little importance on the diet. All of the food observed items were produced by at least one of the studied small farmers, except rice, pasta, beef, and sometimes potato. Milk and fruits were not sampled, but their role in the diet increased during the harvest season.

As previously mentioned, most of the food items observed in the diet are produced by the families, either for self-consumption or for commercialisation. It is important to mention that several types of food, mainly when produced in large quantities, are sold or exchanged among neighbours as a gift or reward for favours. This practice is an important strategy to increase diet diversification and to promote the group cohesion.

TABLE 1

Consumption frequency of food itemsin the studied community.

\begin{tabular}{|l|c|c|c|}
\hline Food items & Sept. 95 & Dec. 95 & Apr. 96 \\
\hline Rice & $100 \%$ & $100 \%$ & $95 \%$ \\
\hline Beans & $100 \%$ & $100 \%$ & $90 \%$ \\
\hline Chicken & $50 \%$ & $36.7 \%$ & $25 \%$ \\
\hline Lettuce & $42.3 \%$ & $6.7 \%$ & $5 \%$ \\
\hline Potato & $23.1 \%$ & $56.7 \%$ & $30 \%$ \\
\hline Tomato & $19.2 \%$ & $20 \%$ & $10 \%$ \\
\hline Pasta & $15.4 \%$ & $20 \%$ & $35 \%$ \\
\hline Beef & $15.4 \%$ & $13.3 \%$ & $5 \%$ \\
\hline Carrots & $11.5 \%$ & $13.3 \%$ & $10 \%$ \\
\hline Pumpkin & $7.7 \%$ & $10 \%$ & $40 \%$ \\
\hline Pork & $7.7 \%$ & $10 \%$ & $20 \%$ \\
\hline Mugango & $7.7 \%$ & $6.7 \%$ & - \\
\hline Greens & $3.8 \%$ & $6.7 \%$ & - \\
\hline Corn fuba & $7.7 \%$ & $6.7 \%$ & - \\
\hline Onions & - & $10 \%$ & $5 \%$ \\
\hline Chayote & - & $3.3 \%$ & $20 \%$ \\
\hline Beetroot & $11.5 \%$ & - & - \\
\hline Eggs & $7.7 \%$ & - & - \\
\hline Green bean & - & $16.7 \%$ & - \\
\hline Cabbage & - & $6.7 \%$ & - \\
\hline Cucumber & - & $3.3 \%$ & - \\
\hline Manioc & - & $3.3 \%$ & - \\
\hline Sweet corn & - & - & $15 \%$ \\
\hline
\end{tabular}


The food niche breadth obtained in this study was 7.82 or $31 \%$ of the maximum width, considering a richness of 23 food items among the 76 meals evaluated. This value is typical of a narrow food niche and reveals a marked dependence on some food items (Fig. 1). This dependence is clearly showed by rice and beans, which are not produced by the studied families, but are bought in the market. The small farmers can balance the rice and beans dependence producing a high variety of food items. These produced food items have use and exchange values combined. Food has use values when are consumed by the families. The exceeding food, has exchange value, when are exchanged among families or sold in the market. The combined production between use and exchange values gives to the studied small farmers, the capacity to maintain a relatively independence of the market.

Nutrition studies of different populations, especially in developing countries, have been largely emphasised in terms of social, economical, political and cultural relations (Victoria \& Vaughan, 1985; Fleuret \& Fleuret, 1980; Sahn, 1990). One of the most complete reviews on this subject done by DeWalt (1993), demonstrates that the nutritional and feeding conditions of populations in rural regions are related to factors of several orders. This factors are found on studied rural producers. Except for a single case, they owns the land that occupy, have all control over the cattle breeding and posses the agriculture for subsistence together with productive activities for commercialisation. They also exchange food items among the families, fact that increases diet diversification and guarantees family autonomy in food supply, and, in addition, to help the maintenance of the internal social cultural equality.

An evaluation of the anthropometric profile of the same studied agriculture workers was done by Cavallini (2001), based on measures of weight and height of the individuals. This study showed the existence of an adequate ration between food ingest and daily caloric needs. The estimations made by the author to determine the caloric value of the family ingests indicated a average input of $47.03 \pm$ $5.89 \mathrm{kcal} / \mathrm{kg} /$ day. Based on Pellet (1990), this caloric input level can be considered satisfactory. to supply the necessity of energy for agricultural activities.

The overlap index was determined, using the measures of niche breadth, for the periods when ingest was evaluated (Fig. 2). A marked overlap of niches is observed during the studied period, ranging from $72 \%$ to $80 \%$, showing the low seasonal variation on the diet. This result is attributed to the strongest dependence of the community on certain food items during the year (Fig. 1). This means that there is a significant independence of environmental variations over consumption of the most frequent food items. This is also related to the ability to stock food (beans and corn to feed chicken and pork), as well as to the possibility of food acquisition on the market (rice, potato, pasta, among others). According to this, the financial flux acts as means to decrease the differential offer of food items of local productive systems, which results from seasonal variations in the natural environment. Nevertheless, it is possible to observe a gradual displacement of the food niche. The overlap level is lower between not adjacent periods. This is mainly related to less frequent food items, whose production is more susceptible to climatic variations.

Considering the niche overlap of families separately and using grouping analysis, it was possible to note some particularities with respect to the degree of inter-familiar similarity on diet (Fig. 3). According to Fig. 3, three groups may be distinguished:

- Group 1: families 7, 9, 4, 5 and 8, which exhibit the greater similarity in diet composition. All the families are producer of milk and owners of land with more than 20 ha.

- Group 2: families 1 and 6, which are less similar on diet, comparatively to the former group. They are owners of land areas with more than 20 ha and are producers of milk and "aguardente" (brandy sugar cane alcohol drink). This is an activity that has gained increasing importance in economical terms.

- Group 3: families 2 and 10, whose diets differ from the two preceding groups. One of these families is not a landowner. The other is a landowner, but his area is smaller than 2 ha. Both families displayed smaller food autonomy than the others, because they bought the majority of food in the market. This fact reinforces the similarity of both families and the difference with the other family groups. 


\section{CONCLUSION}

The present study showed that, despite of relatively small number of food items, the food standard of the studied small farmer families seems to be suitable, particularly concerned to caloric input and diet diversification. This work also showed that the combined production between use and exchange values gives to the small farmers relative independence to the market and allows them to have self-sufficiency and suitable food condition. This study allowed to observe that the families food selfsufficiency is high, since in average, half of the food intake is attained from items produced by themselves in their own properties. The exchange of work and food among studied families permit the establishment of reciprocal altruism as a base for social cohesion.

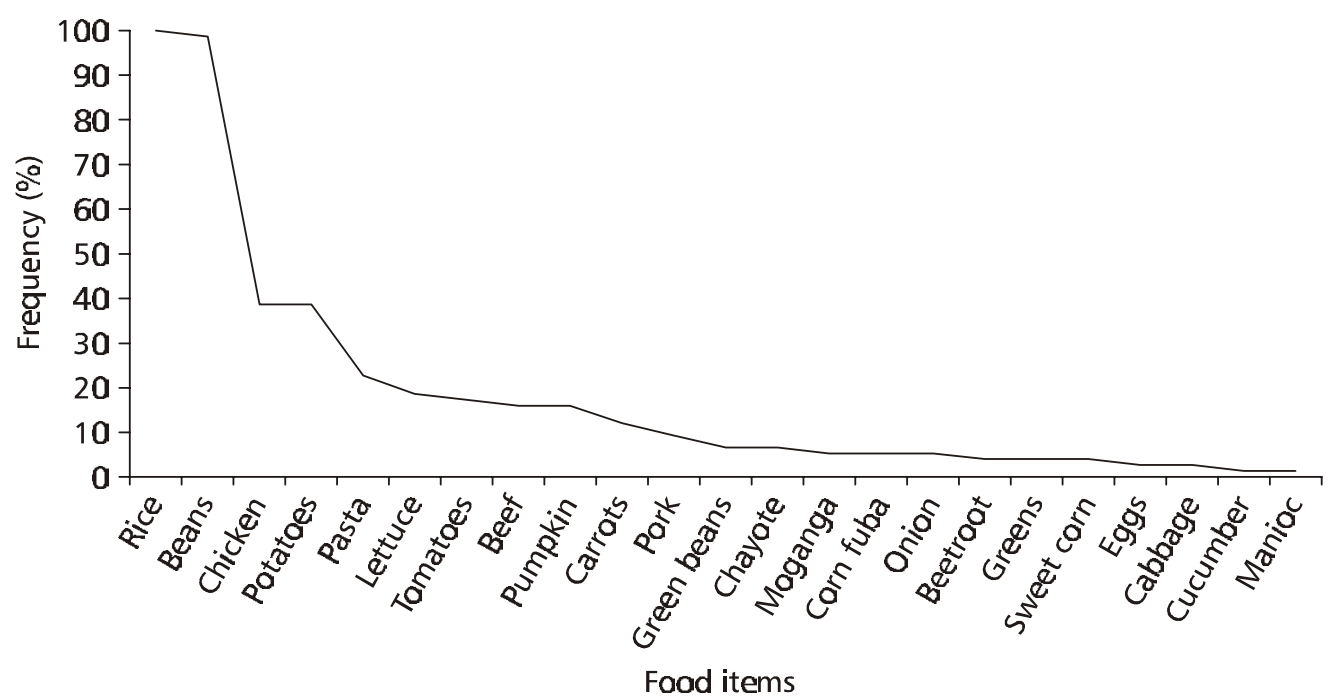

Fig. 1 - Curve of the dominance or importance component of observed food items during the times of study.

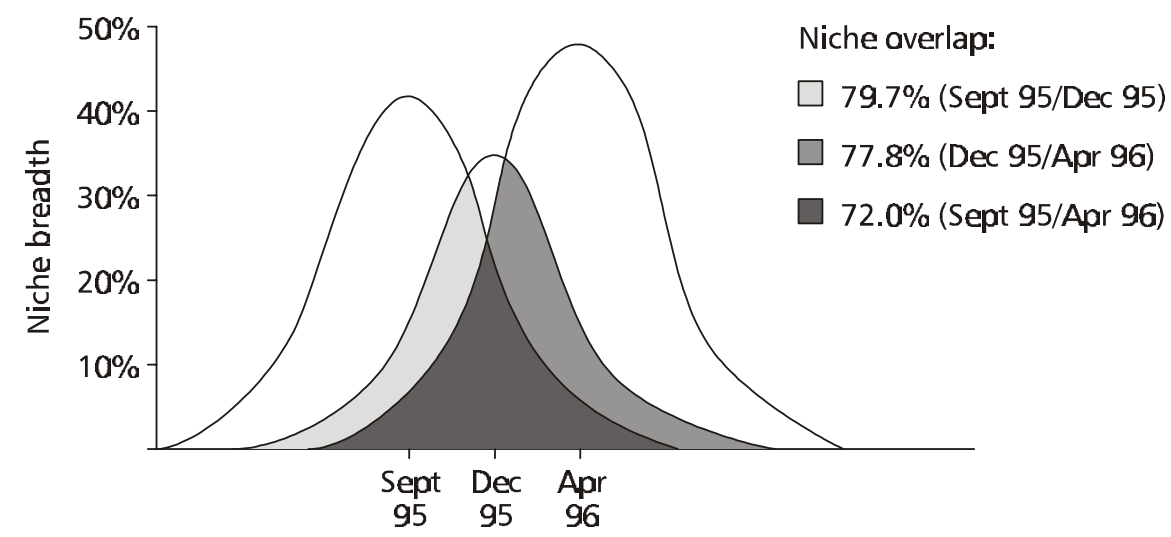

Fig. 2 - Breadth and overlap of food niche at different times of the year. 


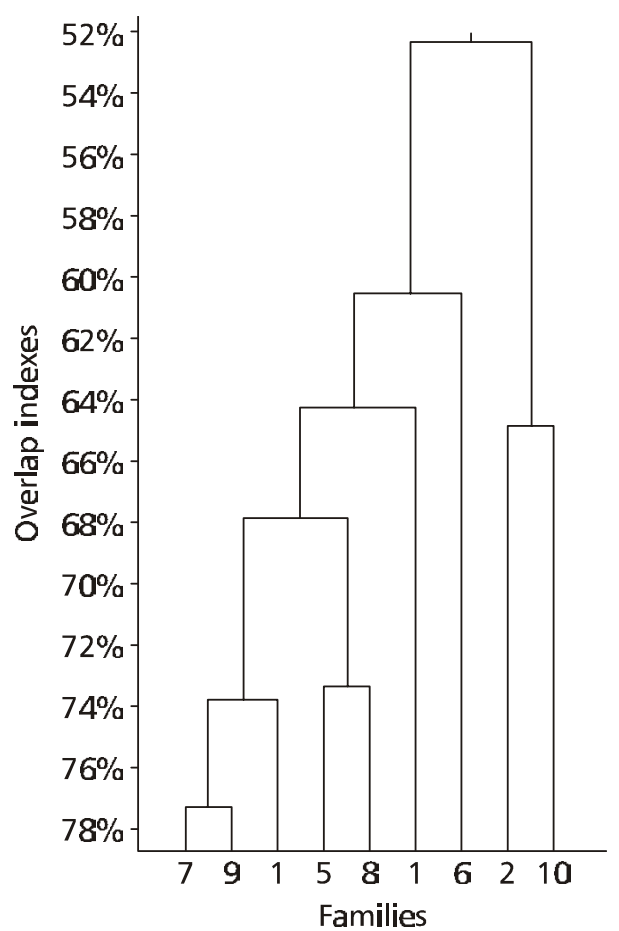

Fig. 3 - Grouping analysis as a function of food niche overlap.

\section{REFERENCES}

BEGON, M., HAPER, J. L. \& TOWNSEND, C. R., 1988, Ecología, individuos, poblaciones y comunidades. Ediciones Omega, 886p.

BEGOSSI, A., 1994, The application of ecological theory to human behavior: niche, diversity and optimal foraging. The Seventh International Conference of the Society for Human Ecology, Michigan State University, April 21-24, p. 2-18.

CAVALLINI, M. M., 2001, Agricultura tradicional, composição paisagística e conservação de biodiversidade na região sul mineira: subsidios ao desenvolvimento rural sustentável. Tese de Doutorado, UFSCar, p. 174.

DeWALT, K. M., 1993, Nutrition and the commercialisation of agriculture: ten years later. Soc. Sci. Med., 32(11): 1407-1416.

FLEURET, P. \& FLEURET, A., 1980, Nutrition, consumption, and agricultural change. Human Organization, 39(3): 250257.

HARDESTY, D. L., 1975, The niche concept: suggestions for its use in human ecology. Human Ecology, 3(2): 71-85.

HARDESTY, D. L., 1972, The human ecological niche. American Anthropologist, 74(3): 458-466.
HUTCHINSON, G. E., 1957, Concluding remarks. Cold Spring Symposiun Quantity Biology., 22: 415-427.

KREBS, C. J., 1989, Ecological methodology. Harper Collins Publishers, New York, USA, p. 654.

PELLETT, P. L., 1990, Food energy requirements in humans. American Journal Clinical Nutrition, 51: 711-722.

QUEIROZ, M. I. P., 1976, O campesinato brasileiro. Ed. Vozes, Petrópolis, RJ, 242p.

SAHN, D. E., 1990, The impact of export crop production on nutritional status in Coste d'Ivore. World Development, 18 : $1635-1653$

TOLEDO, V. M., 1990, The ecological rationality of peasant production. In: M. A. Altieri \& S. B. Hecht, Agroecology and small farm development. CRC Press, Boston, pp. 53-60.

VICTORA, C. G. \& VAUGHAN, J. P., 1985, Land tenure patterns and child health in Southern Brazil: the relationship between agricultural production, malnutrition and child mortality. International Journal of. Health Service., 15(2): 253-273. 